\title{
Chemical Fractions of Iron and Manganese with Different Physico- Chemical Properties in Polyhouse Soils of Himachal Pradesh, India
}

\author{
Ankush Mogta* and Uday Sharma \\ Department of Soil Science and Water Management, Dr. YS Parmar University of \\ Horticulture and Forestry, Nauni, Solan, India \\ *Corresponding author
}

\section{A B S T R A C T}

Polyhouse technology has potential to achieve production to the tone of about Four to five times than open cultivation, but gradually soil fertility get exhausted in the period of 5 to 7 years. Micronutrients are one of the essential components of soil system that plays a significant role in balanced plant nutrition. The present study was conducted on 56 soil

\section{Keywords}

Micronutrients,

Fractions,

Polyhouse soils

\section{Article Info}

Accepted:

16 March 2018

Available Online:

10 April 2018 samples collected from polyhouses of four districts of H.P. to work out the different chemical fractions of iron and manganese and their relation to soil physico-chemical properties. The soil texture varied appreciably from sandy loam, loam to clay loam. Soil $\mathrm{pH}(1: 2)$, OC $\left(\mathrm{g} \mathrm{kg}^{-1}\right)$ and $\mathrm{CEC}\left(\mathrm{cmol}\left(\mathrm{p}^{+}\right) \mathrm{kg}^{-1}\right)$ found in the range of $5.39-7.70,2.40$ 28.50 and 4.00-43.59, respectively. Various $\mathrm{Fe}$ fractions were present in the relative abundance series of water soluble < exchangeable < easily reducible manganese < carbonate bound < organic matter bound < iron and aluminium oxide < residual fraction. Different forms of manganese were present in the order of water soluble < exchangeable < organic matter bound < carbonate bound < iron and aluminium oxide bound < easily reducible manganese $<$ residual. The residual form contributes the greatest among all other fractions. The soil $\mathrm{pH}$ was found to be negatively correlated with various $\mathrm{Fe}$ and $\mathrm{Mn}$ fractions while OC was found to be positively correlated with various fractions. The various fractions were variably correlated with each other showing their interdependence and forms the major source of available pool of micronutrients in soil.

\section{Introduction}

The population of the world has crossed 7.3 billion and may reach 9.7 billion by 2050 . The ever increasing population of the world and decreasing per capita agriculture land holdings may pose a serious threat to the nutritional security. Excessive use of chemical fertilizers and other agricultural chemicals have imbalanced the soil fertility and consequently the productivity is going to be hampered a lot.
In order to restore the natural fertility of the soil, it is essential to study all the essential macro and micronutrients of the soil in totality. Till $21^{\text {st }}$ century our main focus was on macronutrients and little was explored about the labile and non labile pool of micronutrients that serve as the major source for soil available micronutrients. Micronutrients in soil are those essential elements that are required by plants in relatively very small quantity usually less than 
0.1 percent. Micronutrient plays many complex roles in plant nutrition. While most of the micronutrients participate in the functioning of number of enzyme systems, there is considerable variation in the specific functions of the various micronutrients in plant and microbiological growth processes (Brady and Weil, 2013). Iron and Manganese are two of the essential micronutrients that are taken by the plants in higher amount than other micronutrients. In India, the extent of Iron and manganese deficiency was reported to be 12 and 5 per cent, respectively (Singh, 2008). The extent of deficiency in Himachal soils is 27 and 5 per cent respectively for these two micronutrients (Singh, 2009). The availability of these micronutrient cations are largely affected by soil physico-chemical properties. Polyhouse technology has revolutionized the agricultural productivity but at the same time soils becomes exhausted with multinutrient deficiency with 5 to 7 years of production under polyhouse condition.

This happens due to the reason that farmer is aware of only macronutrient fertilizers and not supplementing it with all other essential nutrients in desired proportion that create nutrient imbalance. Most of the studies are only carried out on DTPA extractable micronutrient cations. Thus, present investigation is aimed to study all potential pools of Fe and Mn that are present in soil and the factors which are influencing their solubility and availability in soils under polyhouse condition.

\section{Materials and Methods}

Himachal Pradesh is North Indian state with a varied physiographic condition and elevation that ranges from $450 \mathrm{~m}$ to over $7026 \mathrm{~m}$ amsl characterized by diversity in climate that ranges from sub-tropical in lower hills to alpine in cold deserts of upper Kinnaur and Spiti belt. Different types of soils are observed due to variations in climate, parent material, vegetation and topography. Soil sampling was done in Shimla, Sirmaur, Solan and Bilaspur districts of Himachal Pradesh. Fourteen polyhouses were selected in each district randomly and soil samples were taken from 0 to $15 \mathrm{~cm}$ soil depth. The collected soil samples were air dried and sieved with $2 \mathrm{~mm}$ mesh size sieve for further analysis. Soil texture was done by the standard Bouyoucos hydrometer method (Day, 1965). Soil pH was determined by the glass electrode with calomel as standard (Jackson, 1973). Organic carbon was estimated by wet digestion method of Walkely and Black (1934). The cation exchange capacity was determined by leaching of soil with $1 \mathrm{~N} \quad \mathrm{NH}_{4} \mathrm{OAC}$ and subsequently displacing the adsorbed $\mathrm{NH}_{4}{ }^{+}$with $\mathrm{NaOAC}$ following method of Schollenberger and Simon (1945). Sequential extraction procedure as outlined by Ma \& Uren (1995) was used for evaluation of different fractions of Iron and Manganese with minor modifications.

The surface soil samples were fractionated into various micronutrient fractions viz. water soluble, sorbed (exchangeable), easily reducible manganese, carbonate bound, organic matter, iron and aluminum oxides \& residual. Extraction was done with various reagents, prepared in double distilled water, using 1: 10 soil- solution ratio, except for water soluble, which had 1: 5 ratio of soil and water. The total concentration of the cations was determined after digestion of soil with Aqua regia $\left(\mathrm{HCl}\right.$ and $\mathrm{HNO}_{3}$ in 3:1 ratio). 1 gram soil was digested with $25 \mathrm{ml}$ of freshly prepared Aqua-regia over a hot plate at $110^{\circ} \mathrm{C}$ for 3 hours.

Residual fraction was obtained by subtracting the sum total of different fraction from total content of micronutrients. The constituents in all the extracts were determined on Atomic Absorption Spectrophotometer. The flow sheet of the complete procedure is as follows: 


\section{Flow sheet of sequential extraction of different micronutrient fractions}

Dry Soil (5 g)

$\downarrow$

Distilled water, 1:5, shaking $2 \mathrm{~h}$

$\rightarrow$ Water Soluble

$\downarrow$

$1 \% \mathrm{NaCaHEDTA}$ in $1 \mathrm{M} \mathrm{NH}_{4} \mathrm{oAc}, \mathrm{pH} 8.3,1: 10$, shaking $2 \mathrm{~h} \rightarrow$ Sorbed

(Exchangeable)

$\downarrow$

$0.2 \%$ quinol in $1 \mathrm{M} \mathrm{NH}_{4} \mathrm{OAc}, \mathrm{pH} 7.0,1: 10$, shaking $2 \mathrm{~h}$

$\rightarrow$ Easily Reducible Mn

$0.5 \mathrm{M} \mathrm{Na} / \mathrm{HoAc}, \mathrm{pH} 4.74,1: 10$, soaking $15 \mathrm{~h}$, shaking $3 \mathrm{~h}$

$\rightarrow$ Carbonate Bound

$\downarrow$

$5 \mathrm{~mL} 30 \% \mathrm{H}_{2} \mathrm{O}_{2}, \mathrm{pH} 4.74$, digested twice at $85^{\circ} \mathrm{C}$, and

$\rightarrow$ Organic Matter

extracted by $0.5 \mathrm{M} \mathrm{Na} / \mathrm{HoAc}$ for $1 \mathrm{~h}$

Bound

$0.175 \mathrm{M}\left(\mathrm{NH}_{4}\right)_{2} \mathrm{C}_{2} \mathrm{O}_{4}-0.100 \mathrm{M} \mathrm{H}_{2} \mathrm{C}_{2} \mathrm{O}_{4}, \mathrm{pH} 3.25,1: 10$, soaking $\rightarrow$ Iron and aluminum

$15 \mathrm{~h}$, shaking $2 \mathrm{~h}$.

oxides

$\downarrow$

Total minus Extractable amounts

\section{Results and Discussion}

\section{Physical properties}

\section{Mechanical analysis}

The data regarding soil separates from different locations have been given in table 1 . Soils collected from various locations varied greatly with respect to sand silt and clay contents. Sand, silt and clay contents in the studied soils varied from 14-70, 14-66 and 1037 per cent, respectively. About 52 per cent samples had more than 40 percent sand. About 68 per cent samples were reported to have silt content greater than 30 per cent. Only about 10 per cent samples had clay content greater than 30 per cent. Textural classes varied appreciably from sandy loam, loam to clay loam. Thirty six percent samples fall in loam textural class, 34 per cent samples were clay loam in texture, 16 percent samples were sandy clay loam and remaining 5 per cent each were in sandy loam and silt loam class and rest were silty clay loam. Such variation in soil separates may be attributed to the fact that 
these soils are developed under different climatic conditions, vegetation, geological composition and topographical conditions.

\section{Chemical properties}

Soil pH, organic carbon and cation exchange capacity

The perusal of data in table 1 shows that polyhouse soils under study had wide variations in soil $\mathrm{pH}$, organic carbon (OC) and cation exchange capacity (CEC). Soil $\mathrm{pH}$ ranged from 5.39 to 7.70 with mean value of 6.94. 18 per cent samples had soil $\mathrm{pH}$ below 6.5 , while 23 per cent had $\mathrm{pH}$ greater than 7.3 and remaining majority of samples fell in neutral $\mathrm{pH}$ range. The $\mathrm{OC}$ and $\mathrm{CEC}$ of the polyhouse soils ranged from $2.40-28.50 \mathrm{~g}$ $\mathrm{kg}^{-1}$ and $4.00-43.59 \mathrm{cmol}\left(\mathrm{p}^{+}\right) \mathrm{kg}^{-1}$, with a mean value of $14.63 \mathrm{~g} \mathrm{~kg}^{-1}$ and $22.06 \mathrm{cmol}$ $\left(\mathrm{p}^{+}\right) \mathrm{kg}^{-1} .80$ percent of the soil samples examined had high organic carbon $(>7.5 \mathrm{~g}$ $\left.\mathrm{kg}^{-1}\right)$, while only 11 percent samples were reported to had low OC $\left(<5 \mathrm{~g} \mathrm{~kg}^{-1}\right)$ and rest of the samples were in medium range of soil OC. The wide variation in CEC along different locations may be attributed to the differences in soil texture and soil organic carbon. The higher CEC in the soils having higher organic matter were also reported by Mahajan et al., (2007).

\section{Iron fractions in polyhouse soils}

Data on chemical fractions of $\mathrm{Fe}$ in polyhouse soils of Himachal Pradesh is presented in table 2. The data reveals that the water soluble and exchangeable $\mathrm{Fe}$ in these soils ranged from $3.75-26.06$ and $11.22-69.47 \mathrm{mg} \mathrm{kg}^{-1}$, with mean values of 9.74 and $31.04 \mathrm{mg} \mathrm{kg}^{-1}$, contributing only 0.29 and 0.92 per cent, respectively, of the total $\mathrm{Fe}$ in these soils.

The easily reducible manganese and carbonate bound fractions ranged from $8.11-110.60$ and $32.56-99.06 \mathrm{mg} \mathrm{kg}^{-1}$, with an average content of 39.44 and $71.06 \mathrm{mg} \mathrm{kg}^{-1}$, which was 1.17 and 2.11 per cent, respectively, of the total $\mathrm{Fe}$ in these soils.

Table.1 Physico-chemical properties of polyhouse soils

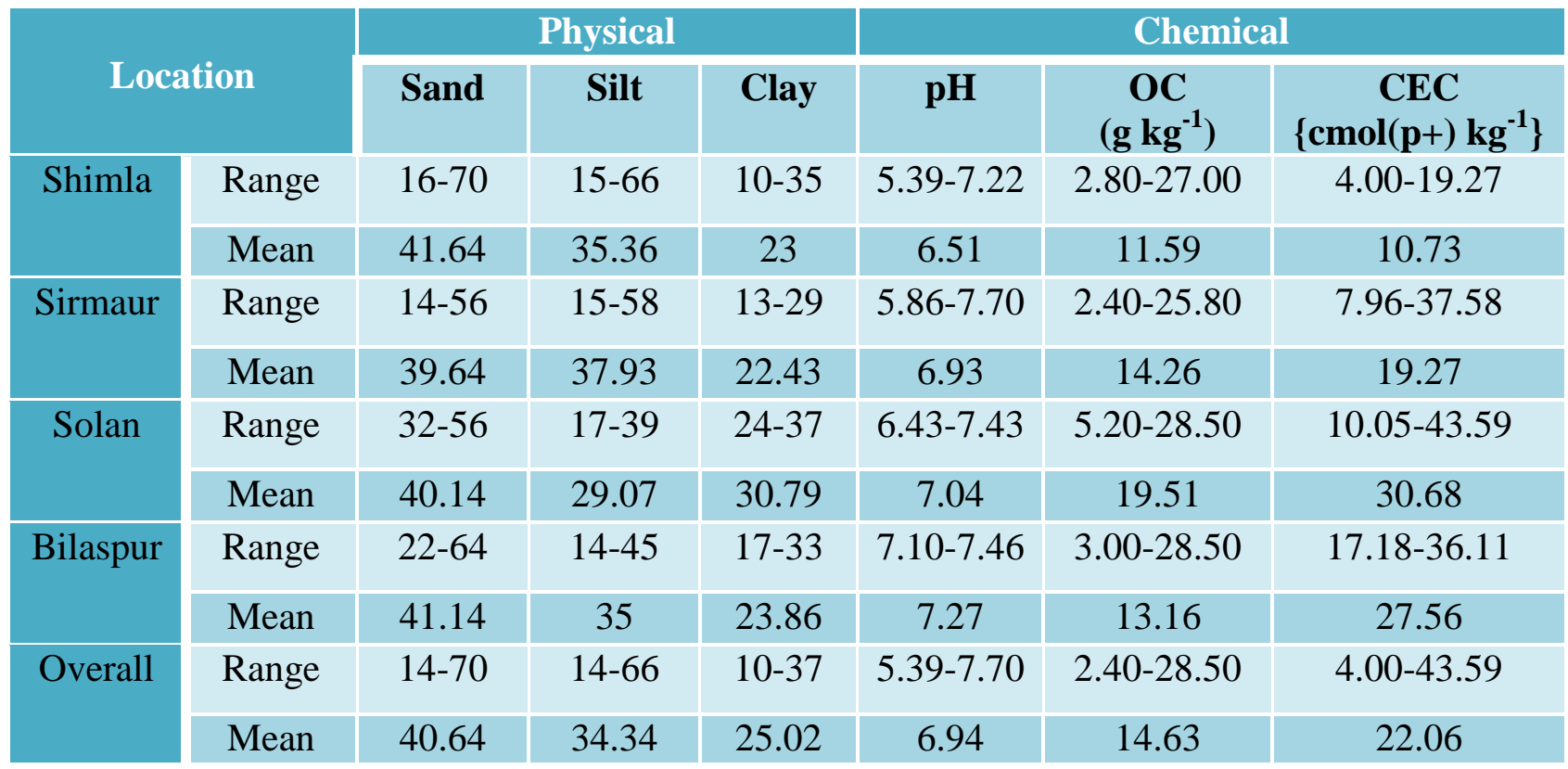


Table. 2 Iron Fractions in polyhouse soils $\left(\mathrm{mg} \mathrm{kg}^{-1}\right)$

\begin{tabular}{|l|c|c|c|c|c|c|c|c|}
\hline \multicolumn{1}{|c|}{ District } & W.S. & Exch. & $\begin{array}{c}\text { ER- } \\
\text { Mn }\end{array}$ & Carbonate & O.M. & FeOx & Residual & $\begin{array}{c}\text { Total } \\
\text { content }\end{array}$ \\
\hline Shimla & 5.59 & 24.04 & 54.17 & 62.29 & 105.60 & 247.45 & 2975.79 & 3474.93 \\
\hline Sirmaur & 10.16 & 31.98 & 53.60 & 76.84 & 90.26 & 246.10 & 2829.77 & 3338.71 \\
\hline Solan & 12.41 & 34.56 & 22.83 & 72.62 & 101.48 & 230.84 & 2943.76 & 3418.50 \\
\hline Bilaspur & 10.82 & 33.60 & 27.14 & 72.48 & 51.32 & 250.44 & 2817.00 & 3262.79 \\
\hline Overall Mean & $\mathbf{9 . 7 4}$ & $\mathbf{3 1 . 0 4}$ & $\mathbf{3 9 . 4 4}$ & $\mathbf{7 1 . 0 6}$ & $\mathbf{8 7 . 1 6}$ & $\mathbf{2 4 3 . 7 1}$ & $\mathbf{2 8 9 1 . 5 8}$ & $\mathbf{3 3 7 3 . 7 3}$ \\
\hline overall Range & $\mathbf{3 . 7 5}-$ & $\mathbf{1 1 . 2 2}-$ & $\mathbf{8 . 1 1}-$ & $\mathbf{3 2 . 5 6 - 9 9 . 0 6}$ & $\mathbf{1 6 . 5 1 -}$ & $\mathbf{1 9 2 . 7 8}-$ & $\mathbf{2 5 2 1 . 4 8}-$ & $\mathbf{2 9 5 5}-$ \\
\hline & $\mathbf{2 6 . 0 6}$ & $\mathbf{6 9 . 4 7}$ & $\mathbf{1 1 0 . 6 0}$ & & $\mathbf{1 6 9 . 2 6}$ & $\mathbf{2 6 7 . 8 0}$ & $\mathbf{3 1 7 8 . 7 8}$ & $\mathbf{3 5 9 3}$ \\
\hline \% contribution & $\mathbf{0 . 2 9}$ & $\mathbf{0 . 9 2}$ & $\mathbf{1 . 1 7}$ & $\mathbf{2 . 1 1}$ & $\mathbf{2 . 5 8}$ & $\mathbf{7 . 2 2}$ & $\mathbf{8 5 . 7 1}$ & $\mathbf{1 0 0 . 0 0}$ \\
\hline
\end{tabular}

Table.3 Manganese fractions in polyhouse soils $\left(\mathrm{mg} \mathrm{kg}^{-1}\right)$

\begin{tabular}{|l|l|l|l|l|l|l|l|l|}
\hline \multicolumn{1}{|c|}{ District } & W.S. & Exch. & $\begin{array}{c}\text { ER- } \\
\text { Mn }\end{array}$ & Carbonate & O.M. & FeOx & Residual & $\begin{array}{c}\text { Total } \\
\text { content }\end{array}$ \\
\hline Shimla & 1.70 & 28.01 & 96.54 & 30.61 & 28.20 & 38.27 & 169.56 & 392.90 \\
\hline Sirmaur & 4.28 & 41.62 & 82.00 & 36.44 & 26.74 & 33.41 & 115.20 & 339.69 \\
\hline Solan & 2.32 & 21.45 & 79.12 & 24.27 & 36.22 & 30.85 & 125.68 & 319.92 \\
\hline Bilaspur & 2.10 & 18.25 & 91.72 & 30.64 & 28.06 & 31.31 & 129.31 & 331.40 \\
\hline Overall Mean & $\mathbf{2 . 6 0}$ & $\mathbf{2 7 . 3 3}$ & $\mathbf{8 7 . 3 4}$ & $\mathbf{3 0 . 4 9}$ & $\mathbf{2 9 . 8 1}$ & $\mathbf{3 3 . 4 6}$ & $\mathbf{1 3 4 . 9 4}$ & $\mathbf{3 4 5 . 9 8}$ \\
\hline overall Range & $\mathbf{1 . 0 0}-$ & $\mathbf{1 0 . 3 6}-$ & $\mathbf{4 2 . 0 2}-$ & $\mathbf{1 8 . 9 4}-$ & $\mathbf{8 . 5 6}-$ & $\mathbf{1 6 . 8 6}-$ & $\mathbf{1 7 . 2 9}-$ & $\mathbf{1 7 4 . 0 0 -}$ \\
\hline & $\mathbf{2 9 . 5 3}$ & $\mathbf{9 5 . 3 7}$ & $\mathbf{1 2 2 . 1 0}$ & $\mathbf{5 0 . 2 7}$ & $\mathbf{6 9 . 1 2}$ & $\mathbf{5 1 . 8 2}$ & $\mathbf{3 1 4 . 5 1}$ & $\mathbf{5 2 3 . 9 0}$ \\
\hline \% contribution & $\mathbf{0 . 7 5}$ & $\mathbf{7 . 9 0}$ & $\mathbf{2 5 . 2 4}$ & $\mathbf{8 . 8 1}$ & $\mathbf{8 . 6 2}$ & $\mathbf{9 . 6 7}$ & $\mathbf{3 9 . 0 0}$ & $\mathbf{1 0 0 . 0 0}$ \\
\hline
\end{tabular}

Table.4 Relationships (r-values) of Iron fractions among themselves and with soil properties

\begin{tabular}{|c|c|c|c|c|c|c|c|c|c|c|c|}
\hline $\mathrm{Fe}$ & pH & $\mathrm{OC}$ & CEC & Clay & W.S. & Exch. & $\begin{array}{l}\text { ER- } \\
\text { Mn }\end{array}$ & Carbonate & O.M. & $\mathrm{FeOx}$ & Residual \\
\hline W.S. & $0.13^{N S}$ & $0.34^{*}$ & $0.45^{* *}$ & 0.16 & & & & & & & \\
\hline Exch. & $-0.37^{* *}$ & $0.44^{* *}$ & $0.34^{*}$ & -0.01 & $0.51^{* *}$ & & & & & & \\
\hline ER-Mn & $-0.51^{* *}$ & -0.18 & $\overline{-}^{-40^{* *}}$ & $0.28^{*}$ & 0.01 & $0.29^{*}$ & & & & & \\
\hline Carbonate & $0.66^{* *}$ & -0.13 & 0.19 & 0.1 & 0.15 & -0.16 & 0.01 & & & & \\
\hline O.M. & $-0.45^{* *}$ & $0.46^{* *}$ & -0.14 & 0.12 & 0.2 & 0.2 & $0.36^{* *}$ & -0.2 & & & \\
\hline $\mathrm{FeOx}$ & -0.09 & -0.25 & $-0.32^{*}$ & -0.23 & -0.01 & 0.04 & 0.24 & 0.03 & -0.08 & & \\
\hline Residual & -0.05 & -0.23 & 0.07 & 0.09 & $-0.26^{*}$ & -0.24 & $-0.28^{*}$ & -0.2 & -0.13 & 0.09 & \\
\hline $\begin{array}{l}\text { Total } \\
\text { content }\end{array}$ & -0.24 & -0.15 & -0.01 & 0.06 & -0.14 & -0.6 & 0.03 & -0.17 & 0.17 & 0.23 & $0.92^{* *}$ \\
\hline
\end{tabular}

**.Significant at the 0.01 level

*. Significant at the 0.05 level 
Table.5 Relationships (r-values) of manganese fractions among themselves and with soil properties

\begin{tabular}{|l|l|l|l|l|l|l|l|l|l|l|l|}
\hline \multicolumn{1}{|c|}{ Mn } & pH & OC & CEC & Clay & W.S. & Exch. & ER-Mn & Carbonate & O.M. & FeOx & Residual \\
\hline W.S. & -0.05 & -0.03 & -0.06 & 0.05 & & & & & & & \\
\hline Exch. & $-0.27^{*}$ & -0.07 & -0.23 & -0.19 & $0.51^{* *}$ & & & & & & \\
\hline ER-Mn & 0.01 & -0.25 & -0.26 & -0.1 & 0.07 & 0.24 & & & & & \\
\hline Carbonate & $0.30^{*}$ & -0.26 & $-0.28^{*}$ & $-0.29^{*}$ & 0.16 & $0.38^{* *}$ & $0.42^{* *}$ & & & & \\
\hline O.M. & -0.07 & $0.73^{* *}$ & $0.38^{* *}$ & 0.25 & -0.01 & -0.08 & $-0.27^{*}$ & $-0.28^{*}$ & & & \\
\hline FeOx & -0.25 & -0.1 & $-0.56^{* *}$ & -0.03 & 0.01 & $0.30^{*}$ & $0.36^{* *}$ & $0.28^{*}$ & -0.21 & & \\
\hline Residual & -0.06 & -0.18 & -0.23 & -0.01 & -0.23 & -0.14 & $0.37^{* *}$ & 0.12 & -0.24 & 0.23 & \\
\hline $\begin{array}{l}\text { Total } \\
\text { content }\end{array}$ & -0.11 & -0.14 & $-0.33^{*}$ & -0.06 & 0.02 & 0.26 & $0.66^{* *}$ & $0.39^{* *}$ & -0.16 & $0.44^{* *}$ & $0.86^{* *}$ \\
\hline
\end{tabular}

** Significant at the 0.01 level; * Significant at the 0.05 level

The organic matter and Iron oxide bound fraction ranged from $16.51-169.26$ and 192.78 - $267.80 \mathrm{mg} \mathrm{kg}^{-1}$, with mean content of 87.16 and $243.71 \mathrm{mg} \mathrm{kg}^{-1}$, constituting 2.58 and 7.22 per cent, respectively, of the total Fe in these soils. The residual Fe fraction ranged between 2521.48 and $3178.78 \mathrm{mg} \mathrm{kg}^{-1}$, with a mean value of $2891.58 \mathrm{mg} \mathrm{kg}^{-1}$. Residual iron was the dominant fraction among all the iron fractions studied soils. The residual fraction was 85.71 per cent of the total Fe content in these soils.

Total Fe content in the studied polyhouse soils varied between 2955 and $3593 \mathrm{mg} \mathrm{kg}^{-1}$, with an average value of $3373.73 \mathrm{mg} \mathrm{kg}^{-1}$.

Among the different districts, the relative abundance of different fractions of $\mathrm{Fe}$ of the order: W.S. < Exch. < ER-Mn < Carbonate bound < O. M. bound < Fe-Ox bound < Residual, except for Solan and Bilaspur districts, where the order was W.S. $<$ ER-Mn $<$ Exch. $<$ Carbonate bound < O. M. bound < $\mathrm{Fe}-\mathrm{Ox}$ bound $<$ Residual.

The higher amount of easily reducible manganese fraction in Shimla and Sirmaur districts might be due to lower $\mathrm{pH}$ of the soils of these two districts. It was observed that 85.71 per cent of the total iron in the studied soils was in the residual fraction. The sufficient amounts of iron in water soluble plus exchangeable forms may be due to slightly acidic to neutral soil reaction of the soils which ultimately affects the solubility of iron. Thus, overall the plant available forms of iron i.e. water soluble, exchangeable and organic matter bound fractions together constituted 3.79 per cent of the total iron in soil which comes out to be $127.94 \mathrm{mg} \mathrm{kg}^{-1}$ indicating a sufficient supply. The comparatively high level of iron oxide bound $\mathrm{Fe}$ fractions also may be ascribed to acidic $\mathrm{pH}$ of the soils. The carbonate bound fractions constituted only 2.11 per cent of the total Fe. This might be due to low carbonates present in the studied soils. The variation in the amount of total iron may be attributed to the fact that these soils have developed over varying parent material. The results are in line with those reported by Sharma and Chaudhary (2007), Sharma et al., (2008).

\section{Manganese fractions in polyhouse soils}

Data on chemical fractions of $\mathrm{Mn}$ in polyhouse soils of Himachal Pradesh is presented in table 3 . The data reveals that the water soluble and exchangeable $\mathrm{Mn}$ in these soils ranged from $1.00-29.53$ and $10.36-$ $95.37 \mathrm{mg} \mathrm{kg}^{-1}$, with mean content of 2.60 and 
$27.33 \mathrm{mg} \mathrm{kg}^{-1}$, constituting only 0.75 and 7.90 per cent, respectively, of the total $\mathrm{Mn}$ in these soils. The easily reducible manganese and carbonate bound fraction ranged from $42.02-$ 122.10 and $18.94-50.27 \mathrm{mg} \mathrm{kg}^{-1}$, with mean content of 87.34 and $30.49 \mathrm{mg} \mathrm{kg}^{-1}$, which were 25.24 and 8.81 per cent, respectively, of the total $\mathrm{Mn}$ in these soils.

The organic matter and Iron oxide bound fraction ranged from $8.56-69.12$ and $16.86-$ $51.82 \mathrm{mg} \mathrm{kg}^{-1}$, with mean content of 29.81 and $33.46 \mathrm{mg} \mathrm{kg}^{-1}$, and were 8.62 and 9.67 per cent, respectively, of the total Mn in these soils. The residual $\mathrm{Mn}$ fraction was the dominant fraction among all the manganese fractions studied ranged between 17.29 and $314.51 \mathrm{mg} \mathrm{kg}^{-1}$, with a mean value of 134.94 $\mathrm{mg} \mathrm{kg}{ }^{-1}$. The residual fraction was 39.00 per cent of the total Mn.

Total Mn content in the studied polyhouse soils varied between 174.00 and $523.90 \mathrm{mg}$ $\mathrm{kg}^{-1}$, with an average value of $345.98 \mathrm{mg} \mathrm{kg}^{-1}$. Abundance of various $\mathrm{Mn}$ fractions was found to be in order of: W.S. < Exch. < O. M. bound < Carbonate bound < $\mathrm{Fe}-\mathrm{Ox}$ bound < ER-Mn < Residual. For Solan district, the order was: W.S. < Exch. < Carbonate bound < Fe-Ox bound < O. M. bound < ER-Mn < Residual. The organic matter bound fraction in case of Solan district was, however, more than the carbonate and iron oxide bound fraction, which can be attributed to high amount of organic carbon in case of Solan district. The high amounts of manganese in water soluble and exchangeable forms may be due to slightly acidic to neutral soil reaction of the soils which ultimately affects the solubility of manganese. Thus, overall the plant available forms of manganese i.e. water soluble, exchangeable and organic matter bound fractions together constituted 17.27 per cent of the total manganese in soils which comes out to be $59.74 \mathrm{mg} \mathrm{kg}^{-1}$ indicating a sufficient supply. The potentially available forms of $\mathrm{Mn}$ are also very high which constitutes easily reducible manganese, carbonate bound and Iron oxide bound fractions together contributing 43.72 per cent of the total $\mathrm{Mn}$ in soils. The comparatively higher level of easily reducible manganese (25.24 per cent) and iron oxide bound $\mathrm{Mn}$ fractions (9.67 per cent) might be due to slightly acidic to neutral $\mathrm{pH}$ of the soils. The high level of manganese bound in easily reducible manganese fraction was also reported by Ma and Uren (1995), Obrador et al., (2007). The carbonate bound fraction, however, constituted only 8.81 per cent of the total Mn, which may be due to low carbonates present in the studied soils. The variation in the amount of total manganese may be attributed to the facts that these soils have developed over varying parent material. The results are in line with those reported by Takkar (1970), Behera et al., (2009), Walna et al., (2010), Sharma and Kanwar (2011) and Behera and Shukla (2014).

\section{Relationships of chemical fractions of iron with soil physico chemical properties}

The data presented in table 4 reveals that the $\mathrm{pH}$ was found to be negatively and significantly correlated with exchangeable $(\mathrm{r}=$ $-0.37 * *)$, easily reducible manganese ( $\mathrm{r}=-$ $\left.0.51^{* *}\right)$ and organic matter bound fraction( $\mathrm{r}=$ $-0.45^{* *}$ ), which suggests that the solubility and availability of these $\mathrm{Fe}$ fractions increases as the $\mathrm{pH}$ decreases. The carbonate bound fraction was found to be positively correlated with soil $\mathrm{pH}\left(\mathrm{r}=0.66^{* *}\right)$, since the $\mathrm{pH}$ increases with the increase in $\mathrm{CaCO}_{3}$ content and vice-versa. Organic carbon was positively correlated with water soluble, exchangeable and organic matter bound fraction of Iron, showing the organic carbon as the source of all these three mobile fractions. $\mathrm{CaCO}_{3}$ content showed negative correlation with Iron oxide bound fraction and total $\mathrm{Fe}$ content, which suggests the lower availability of $\mathrm{Fe}$ in 
high $\mathrm{CaCO}_{3}$ soils. The $\mathrm{CEC}$ was found to be positively correlated with water soluble and exchangeable fractions, which confirms that the CEC is an important property that contributes for plant available forms. Water soluble fraction was positively correlated with exchangeable fraction showing that a dynamic equilibrium exists between these two forms. The residual and total content were found to be highly correlated $(\mathrm{r}=0.92 * *)$ which indicates that the mobility of iron is less and that the stable residual fraction is correlated with the total iron content. The results are in accordance with the findings of Behera et al., (2009) and Jelic et al., (2011)

\section{Relationships of chemical fractions of manganese with soil physico chemical properties}

The $\mathrm{pH}$ was found to be negatively and significantly correlated with the exchangeable fraction of $\mathrm{Mn}\left(\mathrm{r}=-0.27^{*}\right)$, which suggests the lower solubility and availability of this fractions at neutral to higher $\mathrm{pH}$. The carbonate bound fraction was found to be positively correlated with soil $\mathrm{pH}(\mathrm{r}=0.30 *)$, as the carbonates dominate under higher $\mathrm{pH}$ condition. Organic carbon was positively correlated with the organic matter bound fraction of manganese, showing the organic carbon to be a source of the given fraction. The CEC was found to be positively correlated with organic matter bound fraction, which shows their interdependence. Water soluble fraction was positively correlated with exchangeable fraction which indicates the mutual influences of these two forms and their dynamic equilibrium. The easily reducible manganese fraction was found to be positively and significantly correlated with all the fractions except the water soluble and exchangeable fractions. The total content of Mn was found to be highly correlated with easily reducible manganese fraction, carbonate bound, iron oxide bound and residual fractions. Since the mobile fractions are not correlated with total content, hence, the mobility of manganese from unavailable to available fraction confirmed to be very low. The results are in accordance with the findings of Behera et al., (2009), Alvarez et al., (2006) and Obrador et al., (2007) (Table $1)$.

The polyhouse soils of Himachal Pradesh are slightly acidic to neutral in soil reaction. Organic matter content also varied greatly but largely influenced by management practices and CEC was somewhat moderate. Soil texture was variable owing to geology and physiography. Residual fraction in both the micronutrients was the dominant fraction. Fe was mainly found in residual and Iron oxide fractions, whereas, $\mathrm{Mn}$ was found to reside mainly in residual and easily reducible manganese fractions. Extractable fractions were found to be affected by various soil properties. The various fractions were found to be in the dynamic equilibrium with each other as revealed by the relationships among themselves.

\section{References}

Alvarez, J. M., Lopez-Valdivia, L. M., Novillo, J., Obrador, A. and Rico, M.I. 2006. Comparison of EDTA and sequential extraction tests for phytoavailability prediction of manganese and zinc in agricultural alkaline soils. Geoderma, 132: $450-463$.

Behera, S.K. and Shukla, A.K. 2014. Total and Extractable Manganese and Iron in Some Cultivated Acid Soils of India: Status, Distribution and Relationship with Some Soil Properties. Pedosphere, 24(2): 196208.

Behera, S.K., Singh, D. and Dwivedi, B.S. 2009. Changes in Fractions of Iron, Manganese, Copper and Zinc in Soil under Continuous Cropping for More Than Three Decades. Communications in 
Soil Science and Plant Analysis, 40: 1380-1407.

Brady, N.C. and Weil, R.C. 2013. The Nature and Properties of soils, 14th Ed. Revised. Dorling Kindersley India Pvt. Ltd., New Delhi, India. 648p.

Day, P.R. 1965. Particle fraction and particle size analysis. pp. 545-567 in: C.A. Black, (eds.) Methods of Soil Analysis. Part 1. Agronomy 9. American Society of Agronomy, Madison, WI.

Jackson, M.L. 1973. Soil chemical analysis. Prentice Hall of India. Pvt. Ltd., New Delhi.

Jelic, M.Z., Milivojevic, J.Z., Trifunovic, S.R., Dalovic, I.G., Milosev, D.S. and Seremesic, S.I. 2011. Distribution and forms of iron in the vertisols of Serbia. $J$. Serbian Chem. Soc., 76 (5): 781-794.

Ma, Y.B. and Uren, N.C. 1995. Application of a new fractionation scheme for heavy metals in soils. Communications in Soil Science and Plant Analysis, 26(19-20): 3291-3303.

Mahajan, A., Sharma, S.K., Gupta, R.D. and Sharma, R. 2007. Morphological, physical and chemical properties of soils from North West Himalayas. Bulgarian J. Agric. Sci., 13: 607-618.

Obrador, A., Alvarez, J.M., Lopez-Valdivia, L.M., Gonzalez, D., Novillo, J. and Rico, M.I. 2007. Relationships of soil properties with $\mathrm{Mn}$ and $\mathrm{Zn}$ distribution in acidic soils and their uptake by a barley crop. Geoderma, 137: 432 - 443.

Schollenberger, C.J. and Simon, R.H. 1945. Determination of Exchange capacity and exchangeable bases in soil - ammonium acetate method. Soil Sci., 59: $13-20$

Sharma, B.D., Chahal, D.S. and Singh, P.K. 2008. Forms of iron and their association with soil properties in four soil taxonomic orders of arid and semi-arid soils of Punjab, India. Communications in Soil Science and Plant Analysis, 39: 25502567.

Sharma, J.C. and Choudhary, S.K. 2007. Vertical distribution of micronutrient cations in relation to soil characteristics in lower Shivaliks of Solan districts in North-West Himalayas. Journal of the Indian Society of Soil Science, 55 (1): 4044.

Sharma, V. and Kanwar, B.B. 2011. Manganese status and its relation with soil properties in pea growing soils of high hills dry temperate zone of Himachal Pradesh. Journal of Soils and Crops, 17(2): 201210.

Singh, M.V. 2008. Micronutrient Deficiencies in Crops and Soils in India. In: Alloway B.J. (eds) Micronutrient Deficiencies in Global Crop Production. Springer, Dordrecht.

Singh, M.V. 2009. Micronutrient nutritional problems in soils of India and improvement for human and animal health. Indian Journal of Fertilizers, 5(4): 11-21

Takkar, P. N. 1970. Distribution of iron and manganese in meadow forest non calcic brown and grey brown podsolic soils of Himachal Pradesh (India). Geoderma, 3(3): 215-222

Walna, B., Spychalski, W. and Ibragimow, A. 2010. Fractionation of Iron and Manganese in the Horizons of a NutrientPoor Forest Soil Profile Using the Sequential Extraction Method. Polish J. of Environ. Stud., 19(5): 1029-1037.

\section{How to cite this article:}

Ankush Mogta and Uday Sharma. 2018. Chemical Fractions of Iron and Manganese with Different Physico-Chemical Properties in Polyhouse Soils of Himachal Pradesh, India. Int.J.Curr.Microbiol.App.Sci. 7(04): 1903-1911. doi: https://doi.org/10.20546/ijcmas.2018.704.218 